\title{
Identifikasi Kebutuhan Konsumen Katering Makan Siang Di Lingkup Dosen dan Karyawan Universitas Ahmad Dahlan Yogyakarta
}

\author{
Palupi Melati Pangastuti ${ }^{\text {a,1,*, Rai Rake Setyawan }}{ }^{\text {b,2 }}$ \\ a Bisnis Jasa Makanan UAD, J1. Pramuka No 42 Yogyakarta, 55161, Indonesia \\ b Magister Manajemen UAD, Jl. Pramuka No 42 Yogyakarta, 55161, Indonesia \\ 1palupi.melati@culinary.uad.ac.id \\ * penulis korespondensi
}

\begin{abstract}
Bisma Catering is a teaching factory in the vocational study program Food Service Industry. Bisma Catering's concumers are lecturers and employees at Universitas Ahmad Dahlan. Consumers have different needs and appetites but in this case Bisma Catering had not had data about that. The aim of this study was to identify and documenting the needs of Catering consumers at Universitas Ahmad Dahlan. This research was a quantitative research with survei method. The respondents were 100 lecturers and UAD employees. The instrument was in a google form distributed via whatsapp. The data obtained were further analyzed descriptively. The result showed that $58.7 \%$ of respondents were women. 59,7\% work as lecturers and 40,3\% are employees. 42,9\% of respondents wanted lunch with price range of IDR 13,000-15,000. 91\% wanted vegetables in menu and $64 \%$ wanted sauteed dishes. $45.5 \%$ like the spicy taste and $90 \%$ said there was no food allergy. $48 \%$ customers want plastic lunch box as packaging.
\end{abstract}

Keywords: bisma catering, consumers need identification, food service industri

\section{ABSTRAK}

"Bisma Catering" merupakan teaching factory di program studi vokasi D-IV Bisnis Jasa Makanan. Konsumen Bisma Catering adalah dosen dan karyawan Universitas Ahmad Dahlan. Konsumen memiliki kebutuhan dan selera yang berbeda-beda. Permasalahannya adalah Bisma Catering belum memiliki data akan keinginan dan selera konsumen. Tujuan studi ini adalah untuk mengidentifikasi dan mendokumentasikan kebutuhan konsumen katering di Universitas Ahmad Dahlan. Studi ini merupakan studi deskriptif dengan metode survei. Subyek adalah dosen dan karyawan UAD dengan jumlah (n) 100 orang. Instrumen studi berupa google form yang disebar melalui aplikasi whatsapp. Data yang diperoleh selanjutnya dianalisis secara deskriptif. Hasil studi menunjukkan $58,7 \%$ responden adalah perempuan. $59,7 \%$ berprofesi sebagai dosen dan 40,3\% karyawan. $42,9 \% \%$ responden menginginkan makan siang dengan rentang harga $\mathrm{Rp}$ 13.000-15.000. 44,7\% menyukai rasa sedikit pedas. 93,5\% tidak ada alergi makanan, 93,5\% menyukai sayur dan $67,5 \%$ menginginkan masakan yang ditumis. $48,1 \%$ menginginkan kemasan rantang plastik.

Kata kunci: bisma catering, identifikasi keinginan konsumen, usaha jasa boga

\section{Pendahuluan}

Makan adalah salah satu kebutuhan pokok manusia. Selama manusia masih hidup maka makanan selalu dibutuhkan. Dahulu setiap rumah tangga memenuhi kebutuhan makan dengan memasak setiap hari dan biasanya dilakukan oleh ibu dan anak perempuan. Seiring berkembangnya zaman, manusia semakin sibuk. Banyak wanita bekerja sehingga 
untuk urusan memasak, sering tidak ada waktu. Kaum ibu yang bekerja sering memilih membeli makanan di warung bahkan memanfaatkan kemajuan teknologi dengan melakukan pemesanan melalui telepon genggam untuk mencukupi kebutuhan makan di rumah atau dirinya pribadi. Hal ini tentunya menjadi peluang besar bagi pengusaha katering.

Program Studi Bisnis Jasa Makanan merupakan prodi vokasi sarjana terapan pertama di Universitas Ahmad Dahlan. Berdiri tanggal 19 September 2017 untuk menyiapkan sumberdaya manusia yang handal dalam mengelola bisnis jasa makanan. Prodi Bisnis Jasa Makanan UAD disebut sebagai program studi visioner oleh Direktorat Jenderal Pembelajaran dan Kemahasiswaan merupakan unsur pelaksana di Kementerian Riset, Teknologi, dan Pendidikan Tinggi Republik Indonesia. Sebagai pendukung kegiatan praktik mahasiswa maka Prodi Bisnis Jasa Makanan memiliki unit usaha di bidang pengadaan makanan yang bernama "Bisma Catering". Bisma Catering menjadi teaching factory sesuai konsep vokasi yaitu $70 \%$ berupa praktek. Di Bisma Catering ini mahasiswa belajar untuk merancang, mempersiapkan, mengolah, memorsikan, mengemas, mendistribusikan, sampai menyajikan makanan. Bahkan tidak jarang mahasiswa terlibat dalam perhitungan food costing untuk penentuan harga.

Berdasar Survei Sosial Ekonomi Nasional 2015 (SUSENAS) yang menyebutkan bahwa konsumsi sebagian besar makanan jadi mengalami peningkatan. Peningkatan konsumsi per kapita per tahunnya terlihat pada makanan jadi seperti kue kering/biskuit/semprong /cookies, kue basah, makanan gorengan, gadogado/ketoprak/pecel, nasi campur/rames, nasi goreng, lontong/ketupat sayur, soto/gule/sop, mie bakso/rebus/goreng, makanan ringan anak-anak, ikan goreng/bakar/dsb, serta ayam/daging (goreng, bakar, dsb) (Anonim, 2015). Masyarakat Indonesia lebih banyak mengkonsumsi berbagai macam makanan basah dibandingkan makanan kering. Potensi pasar Bisma Catering sangat besar. Di Universitas Ahmad Dahlan jumlah dosen dan karyawan sebanyak 600 orang. Bisma Catering sudah melayani konsumen di UAD satu tahun berjalan. Banyak masukan yang bermanfaat dan Bisma Catering terus melakukan perbaikan diri dalam hal pelayanan penyediaan makanan di Universitas Ahmad Dahlan.

Kebutuhan dan selera konsumen yang beragam sebaiknya bisa dijembatani oleh Bisma katering dengan menyajikan menu yang sesuai dengan sebagian besar kebutuhan dan selera tersebut. Sehingga perlu memiliki dokumentasi berkaitan dengan hal tersebut. Namun, Bisma catering belum memiliki dokumentasi terkait kebutuhan dan selera konsumen atau kelompok konsumen di lingkup dosen dan karyawan UAD. Sementara, selera atau permintaan konsumen yang pernah memesan sangat beragam.

\section{Metode Penelitian}

Studi ini merupakan peneltian kuantitatif menggunakan metode survei. Kuesioner online dengan google form dikirim melalui aplikasi whatsapp grup maupun secara pribadi. Responden mendapat penjelasan tentang maksud survei tersebut kemudian setelah responden mengisi dan mengirimkan tanggapan, secara otomatis muncul ucapan terima kasih. Tanggapan yang dikirim secara otomatis terekap dalam google drive dan selanjutnya dilakukan analisis secara deskriptif. Descriptive analytic merupakan metode untuk menggambarkan data yang diperoleh secara ilmiah dalam bentuk tabel dan grafik. 
Tidak menjelaskan hubungan antar data tersebut melainkan mengumpulkan data aktual secara sistematis dan cermat (Notoatmodjo, 2012)

Populasi merupakan seluruh sumber data yang diperlukan dalam studi (Saryono, 2011). Populasi dalam studi ini adalah karyawan dan dosen Universitas Ahmad Dahlan sebanyak 1.096. populasi total sebanyak 1.096 orang terdiri dari karyawan UAD sebanyak 374 orang dan dosen UAD berjumlah 722 orang. Sampel adalah bagian dari populasi yang dapat mewakili (Saryono, 2011). Pengambilan sampel pada studi ini dengan metode simple random sampling yaitu cara yang dapat digunakan untuk mengambil sampel pada suatu populasi yang heterogen (Notoatmodjo, 2012). Jumlah sampel yang diambil sebanyak 100 orang.

$$
\mathrm{n}=\frac{\mathrm{N}}{1+\mathrm{N}(\mathrm{d})^{2}}
$$

$\mathrm{n}=$ Jumlah sampel

$\mathrm{N}=$ Jumlah populasi

$\mathrm{d}=$ derajat penyimpangan terhadap populasi yang diinginkan $10 \%, 5 \%$, atau $1 \%$ Jumlah populasi $(\mathrm{N})=1096$

Maka jumlah sampel (n) minimal dengan d 10\% adalah 92 orang. Jumlah sampel minimal ditambah $10 \%$ untuk antisipasi sehingga sampel yang dipakai dalam studi ini adalah 100 orang.

Kriteria inklusi sampel pada studi ini adalah seluruh dosen dan karyawan Universitas Ahmad Dahlan yang bersedia meluangkan waktu mengisi kuesioner. Sedangkan kriteria eksklusi dari studi ini adalah subjek membatalkan kesediannya untuk menjadi responden dan subjek yang belum mengenal maupun memesan di Bisma Catering.

\section{Hasil dan Pembahasan}

\subsection{Karakteristik Responden}

Jumlah responden yang mengisi kuesioner sebanyak 100 orang. Dari 100 orang yang datanya terekap sebanyak $57,1 \%$ adalah perempuan dan $42,9 \%$ nya adalah laki-laki. Berdasarkan profesi, sebagian besar adalah dosen yaitu sebesar $68 \%$ sesuai jumlah dosen Universitas Ahmad Dahlan yang lebih banyak dari karyawan (32\%). Para responden tersebar di Kampus 1, 2, 3, 4, 5, dan kantor Lembaga Studi dan Pengabdian Masyarakat (LPPM) (Gambar 3.1). Sebagian besar responden adalah suku jawa (Gambar 3.2).

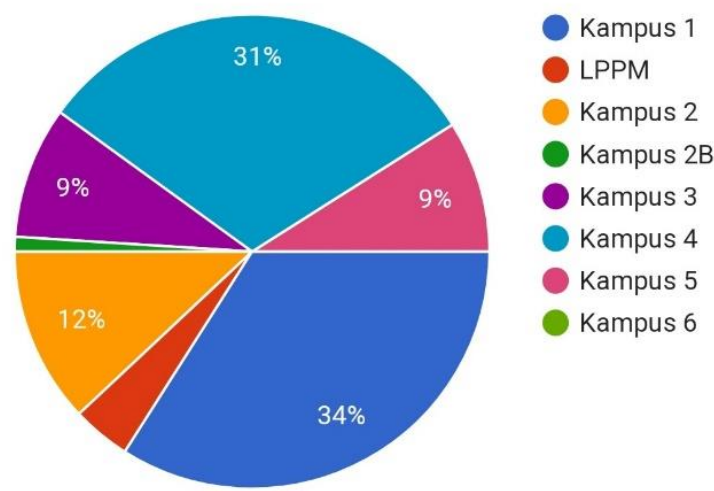

Gambar 3.1. Persebaran Lokasi Responden 


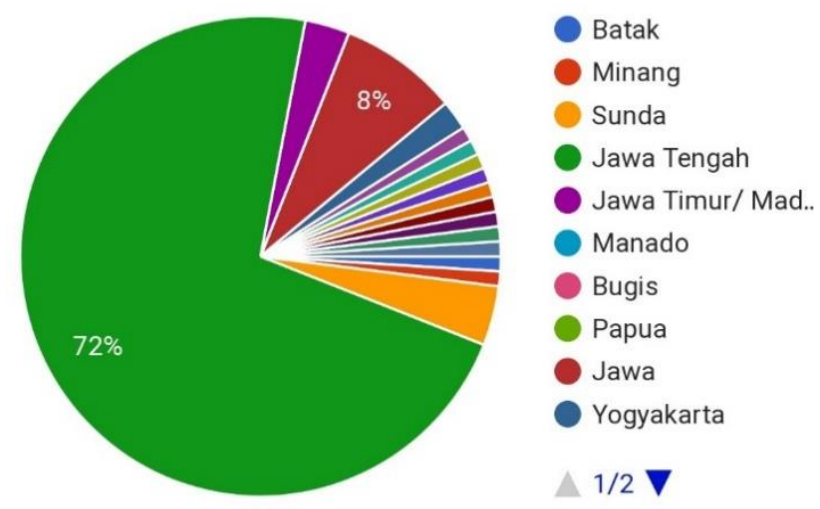

Gambar 3.2. Suku Para Responden

\subsection{Harga dan Jumlah}

Dari 100 orang responden yang ditanya apakah ingin berlangganan katering makan siang di Bisma Catering terdapat 33\% responden yang menginginkan berlangganan, $12 \%$ tidak ingin berlangganan, dan 55\% mungkin berlangganan. Dari responden yang menjawab tidak ingin berlangganan, di antaranya memberikan alasan tidak pastinya jadwal berada di kampus.
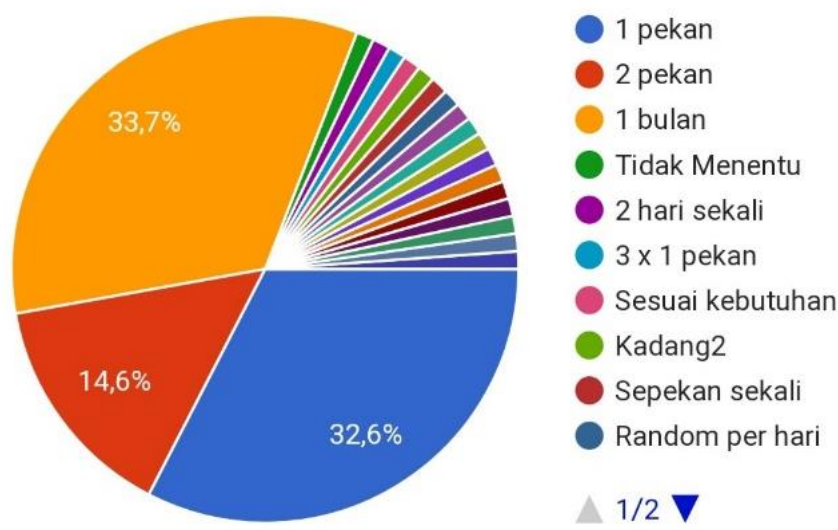

Gambar 3.3. Periode Berlangganan Katering

Dari hasil survei 33,7\% menyatakan mau berlangganan katering makan siang selama satu bulan sementara 32,6\% ingin berlangganan selama satu pekan (Gambar 3.3). Sebanyak 44 responden menginginkan harga katering makan siang berkisar Rp 10.000 12.000 sementara 42 orang menginginkan harga 13.000 - 15.000 (Gambar 3.4).

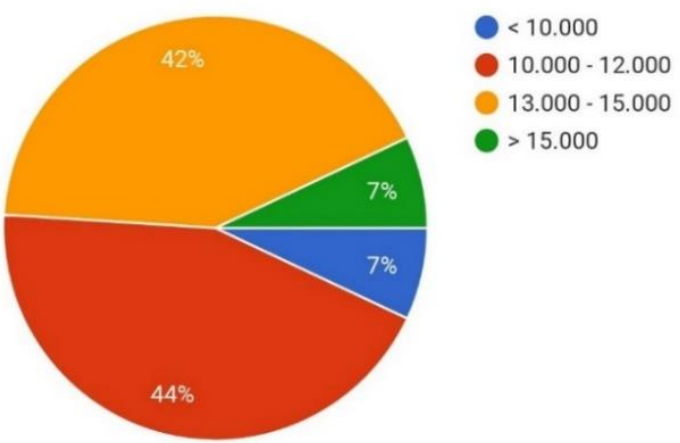

Gambar 3.4. Harga Menu Katering yang Diinginkan 


\subsection{Pilihan Menu dan Kemasan}

Bisma Catering menawarkan berbagai pilihan menu seperti nasi, sayur, lauk nabati, lauk hewani, buah, sambal dan kerupuk. Sayur diinginkan oleh $91 \%$ responden, nasi diinginkan oleh $80 \%$, lauk hewani diinginkan oleh $79 \%$, sementara lauk nabati diinginkan oleh $70 \%$ responden. Untuk condiment atau pelengkapnya yaitu buah, kerupuk, dan sambal. $73 \%$ responden menginginkan buah, $68 \%$ menginginkan adanya sambal, dan $52 \%$ menginginkan kerupuk.

Peneliti juga mensurvei selera pedas konsumen Bisma Catering. Ternyata $87 \%$ menyukai level sedikit pedas sampai pedas, sementara hanya $5 \%$ yang menyukai level sangat pedas, dan selebihnya $8 \%$ tidak suka pedas.

Berdasar tipe olahannya, menu Bisma Catering ada hidangan berkuah banyak, berkuah sedikit, tumis, goreng, bakar, kukus, panggang. Dari 100 orang responden 64 orang atau 64\% memilih olahan tumis, 56 orang memilih berkuah sedikit, 38 memilih goreng, 36 memilih berkuah banyak. Sementara olahan bakar, kukus dan panggang masing-masing diinginkan oleh 2 orang responden.

Untuk kemasan yang ditawarkan menggunakan kertas nasi, kardus nasi, bento sekali pakai dan rantang plastik. 48\% lebih memilih kemasan rantang plastik dengan alasan dapat dicuci dan digunakan kembali, mengurangi sampah. Kertas nasi dan kardus nasi dipilih oleh masing-masing $18 \%$ responden, sementara bento sekali pakai dipilih oleh $16 \%$ responden.

Sehingga Bisma Catering menyusun daftar menu sebagai berikut:

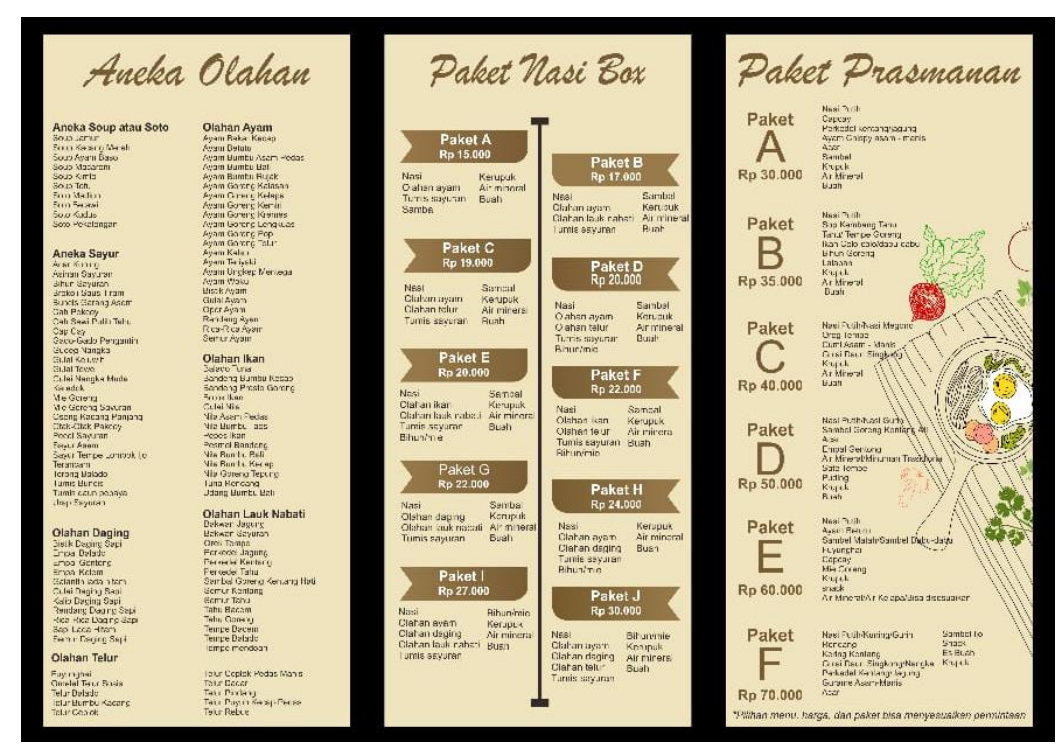

Gambar 3.5. Daftar Menu Bisma Catering

\section{Kesimpulan}

Hasil survei menunjukkan $42,9 \% \%$ responden menginginkan makan siang dengan rentang harga $\mathrm{Rp}$ 13.000-15.000. 44,7\% menyukai rasa sedikit pedas. $48,1 \%$ menginginkan kemasan rantang plastik. 93,5\% tidak ada alergi makanan, 93,5\% menyukai sayur dan 67,5\% menginginkan masakan yang ditumis. 


\section{Pustaka}

Anonim. 2015. Statistik Konsumsi Pangan Tahun 2015. Jakarta.

Arianto, M., \& Mahmudah, N. 2014. "Analisis Kepuasan Konsumen Consumer Satisfaction Analysis Abstrak", dalam Jurnal Bisnis, Manajemen \& Perbankan. Vol. 1, No. 2: 102-120.

Fadiati, A. 2013. Mengelola Usaha Jasa Boga Yang Sukses (2nd ed.). Bandung: Remaja Rosdakarya.

Gardjito, M., Hendrasty, H. K., \& Dewi, A. 2016. Industri Jasa Boga. Yogyakarta: Gadjah Mada University Press.

KBBI. (n.d.). Retrieved from https://kbbi.web.id/konsumen

Kotler, P., \& Keller, K. L. 2016. Marketing Management (15th ed.). London: Pearson Education, Inc.

Notoatmodjo, S. 2012. Metode Studi Kesehatan. Jakarta: Rineka Cipta.

Prabowo, P. A. 2013. "Analisis Perilaku Konsumen Jasa Katering Untuk Keperluan Pesta di Surabaya”, dalam Calyptra: Jurnal Ilmiah Mahasiswa Universitas Surabaya. Vol. 2, No. 1: 1-9.

Saryono. 2011. Metodologi Studi Keperawatan. Purwokerto: UPT. Percetakan dan Penerbitan UNSOED. 